\title{
Energy utilization for body weight gain of ram-lambs fed differently processed breadfruit (Artocarpus altilis) meal in total mixed rations * Okoruwa, M. I.
}

Department of Animal Science, Ambrose Alli University, P. M. B. 14. Ekpoma, Edo State, Nigeria.

*Corresponding author E-mail: odionokos@yahoo.com; okosmich@gmail.com

\begin{abstract}
The study was carried out to estimate the energy utilization for body weight gain in West African dwarf ram-lambs fed differently processed breadfruit meal in total mixed rations. Twenty non-castrated ram-lambs, about 7months of age with an average-initial body weight of $6.00 \pm 0.55 \mathrm{~kg}$, were randomly assigned to four dietary treatments with five ram-lambs per treatment group in a completely randomized design. Ficus foliage with differently processed breadfruit meals and concentrate diet were used as treatment diets. Diet A $50 \%$ unpeeled raw breadfruit meal $+20 \%$ Ficus foliage $+30 \%$ concentrate diet) B $(50 \%$ peeled raw breadfruit $+20 \%$ Ficus foliage $+30 \%$ concentrate diet), C (50\% unpeeled soaked breadfruit meal $+20 \%$ Ficus foliage $+30 \%$ concentrate diet) and D (50\% unpeeled boiled breadfruit meal $+20 \%$ Ficus foliage $+30 \%$ concentrate diet). Results showed that faecal energy output $(999.41 \mathrm{MJ} / \mathrm{g} /$ day DM) was significantly $(P<0.05)$ highest in treatment diet A compared with other treatment diets. Ram-lambs on treatment diets $B$ and $C$ had the significantly highest $(P$ $<0.05)$ on digestible energy intake (1310.84 and $1295.62 \mathrm{MJ} / \mathrm{g} /$ day DM), metabolizable energy intake (1074.89 and $1062.41 \mathrm{MJ} / \mathrm{g} /$ day DM), average total weight gain (4.18 and $4.13 \mathrm{~kg})$ and average daily weight gain (87.08 and $86.04 \mathrm{~g})$ compared with treatment diets $A$ and D. Gross energy intake $(4503.00 \mathrm{MJ} / \mathrm{g} /$ day), average total feed intake (13.68kg), average daily feed intake $(285.00 \mathrm{~g})$ and feed conversion ratio (4.44) were significantly $(P<0.05)$ better in ram-lambs on treatment diet $D$. There were no significant $(P>0.05)$ differences in urinary energy loss, metabolizability and initial body weight of ram-lambs. It was therefore concluded that diets $B$ and $C$ enhanced efficiency of energy utilization for body weight gain of ram-lambs.
\end{abstract}

Keywords: Energy, growth, ficus foliage, breadfruit meal, sheep

\section{Introduction}

Small ruminant production has emerged as having an unquestionable propensity to close the existing gap in animal protein consumption in the tropics. This is because of their large number, greater affordability compared with cattle and wide acceptance of their products for human consumption. However, energy is one of the limiting factors to effective small ruminant production in the tropics. Inadequate supply of conventional energy feedstuffs due to competition between man and livestock have been one of the major reasons for their scarcity (Ajayi et al., 2005; Kamalzadeh and Shabani, 2007). Thus, the need to replace conventional energy feeds with less - known readily available energy feed resources is considered in order to minimize cost and maximize ruminant production. To combat this challenge, the use of alternative feed sources has been canvassed. Hence, there is a constant need to look for locally available sources of energy feed ingredients, particularly those feeds that are less known in livestock production. The recognition of less-known energy-rich fruit sources and multipurpose 


\section{Weight gain of ram-lambs fed differently processed breadfruit meal}

tree foliage has gained prominence because of its availability, cheap and perhaps most abundant potential sources of energy in the southern Nigeria (Oladunjoye et al., 2010).

Breadfruit (Anocarpus altilis) is one of such fruits that have been successfully introduced to the forest zone of southern Nigeria. Breadfruit has a great productive ability and its production usually exceeds demand in the major producing areas in southern Nigeria. It is regarded as an energy food, a source of complex carbohydrates, vitamins and minerals (Oladunjoye et al., 2010; Zhou et al., 2014). Though, breadfruit is yet to be thoroughly evaluated, it represents is a potentially important source of energy for livestock production, when properly processed. Ficus (Ficus thionning) plants belong to the family of Moracea which are often distinguished by their fruit growing plants. Ficus species are evergreen plants that can be used as a potential source of forage for improving utilization of feeds in ruminants (Ajayi et al., 2005).

However, there is no sufficient published data on energy content of differently processed breadfruit meal in most practical diets for small ruminants. Fanimo et al. (2006) reported that apparent digestible and metabolizable energy are one of the most practical and useful indicators of dietary energy available from feed ingredients. Hence, the measurement of the dietary energy and nutrient utilization of raw materials is known to be influenced by many factors among which are; rate of inclusion, type of basal diets and processing methods (Okoruwa and Bamigboye, 2015). Notwithstanding, the knowledge of how sheep use the feed energy for its metabolic functions is extremely important, since this efficiency varies according to the physiological state, nutrient requirements, concentration of energy in the diet and feed evaluation. Thus, the objective of this study was to determine the energy utilization for body weight gain of ram-lambs fed differently processed breadfruit meal in total mixed rations.

\section{Materials and Methods Experimental site}

The experiment was conducted at the Small Ruminant Unit of the Teaching and Research Farm, Ambrose Alli University, Ekpoma. Nigeria. Ekpoma is located on longitude $6.09^{\circ} \mathrm{E}$ and latitude $6.42^{\circ} \mathrm{N}$ with a unimodal rainfall pattern, which starts from April and ends in October. The vegetation represents an interface between the tropical rainfall and derived savanna. The mean rainfall and temperature are about $1556 \mathrm{~mm}$ and $31^{\circ} \mathrm{C}$ respectively.

\section{Experimental diets}

Ficus foliage was harvested from a mature tree around the Teaching and Research Farm at the Ambrose Alli University, Ekpoma. The foliages were chopped into small sizes of about $5 \mathrm{~cm}$ before being used. Breadfruits were harvested in a farm plantation around Ekpoma in Edo - State, Nigeria. The breadfruits were differently processed into meals in the following ways: URBM =Slicing-Sun drying-Milling PRBM =Peeling -Slicing-Sun dry-Milling USBM = Slicing -soaking-Sun dry-Milling UBBM =Slicing-Boiling-Sun dry-Milling $\mathrm{URBM}=$ Unpeeled raw breadfruit meal $\mathrm{PRBM}=$ Peeled raw breadfruit meal USBM $=$ Unpeeled soaked breadfruit meal UBBM = Unpeeled boiled breadfruit meal The ingredient composition of the concentrate diet used in combination with differently processed breadfruit meals and Ficus foliage was: brewer's dried grain, $50 \%$; wheat offal, $35 \%$; rice bran, $10 \%$; vitamin, $1.50 \%$; bone meal, $2 \%$; limestone, $1 \%$ and salt $0.50 \%$.

The prepared breadfruit meals were used in combination with Ficus foliage and 
concentrate diet in ratio 50:20:30 respectively.

Thus, the four experimental diets were: A $(50 \%$ URBM $+20 \%$ Ficus foliage $+30 \%$ concentrate diet), B (50\% PRBM + 20\% Ficus foliage $+30 \%$ concentrate diet), $\mathrm{C}$ $(50 \%$ USBM $+20 \%$ Ficus foliage $+30 \%$ concentrate diet) and D $(50 \%$ UBBM $+20 \%$ Ficus foliage $+30 \%$ concentrate diet). The experimental diets were offered at the rate of $5 \%$ (DM basis) of the animals' body weight (BW).

\section{Experimental animals and management}

Twenty non-castrated West African Dwarf ram-lambs, with an average initial BW of $6.00 \pm 0.55 \mathrm{~kg}$ and approximately 7 months old were used for the study. The ram-lambs were sourced in the villages within Ekpoma metropolis, Edo State, Nigeria. Experimental pens were cleaned and disinfected prior to the arrival of the ramlambs. On arrival, the ram-lambs were given prophylactic treatments against the common viral and bacterial diseases. They were dewormed and bathed to eliminate endo and ecto parasites. After a 14 - day adaptation period, the animals were randomly allocated to the four dietary treatments with five replicates per treatment in a completely randomized design. Thereafter, they were individually housed in open - sided demarcated pens with adequate ventilation. Pens and ramlambs were clearly labelled for proper identification and individual pens were also equipped with troughs for the supply of feeds and water. Experimental diets were fed to the animals twice daily at about 8:00 am in the morning and $4: 00 \mathrm{pm}$ in the evening. They also had free access to fresh cool water. Strict hygiene condition was maintained in the confinement by regular cleaning of the pens and washing of the feeding and water troughs on daily basis with changing of wood shavings fortnightly. The experiment lasted for 12 weeks excluding the 14 days for acclimatization.

\section{Bodyweight gain}

Before the feeds were supplied in the morning to the ram-lambs, leftovers from each animal were collected, weighed and recorded. Thus, the daily feed intake was determined by the difference in weight of quantity of feeds supplied in the morning and the leftover of the previous day's feeds. Body weights of ram-lambs were taken in the morning before feeding on weekly basis by using a hang - scale. Data derived from daily feed intake and daily weight gains were computed and feed conversion ratio was calculated as the ratio of feed intake over the body weight gain.

\section{Energytrial}

At the end of the $10^{\text {th }}$ week of the body weight gain measurement, energy utilization study was carried out on the ramlambs. Four ram-lambs randomly selected from each treatment group were used for the energy trial. Ram-lambs were then transferred to individual metabolism cages with slated floors adapted for urine and faecal collections. The ram-lambs were fed with their treatment diets for 14 days, seven days for adaptation to the metabolism cages while the remaining seven days was used for the collection of samples from feeds, leftover feeds, urine and faeces. The quantity of feeds offered to each ram-lamb was weighed daily and the leftover was collected the following day and weighed as well. Daily faecal and urinary collections were also weighed thereafter $5 \%$ of the subsamples of faeces and urine were then taken from the samples and stored. Subsequently, they formed daily composite sample per animal which at the end of the metabolic trial formed a total composite sample per ram-lamb/diet. However, sampled treatment diets were stored separately in an 
air-tight containers while sampled faeces and urine were stored in a freezer $\left(-10^{\circ} \mathrm{C}\right)$ until they were all required for analysis.

Gross energy (GE) of feeds, faeces and urine was determined using an adiabatic bomb calorimeter. The GE intake was calculated as the GE of the feed in dry matter (DM) multiply by DM of the feed intake, while faecal energy output was determined as the GE of the faeces in DM multiply by the quantity of the faeces in DM. Digestible energy (DE) intake was calculated as the difference between GE intake and faecal energy output divided by GE intake multiply by 100 and GE of the feeds in DM. Metabolizable energy (ME) was estimated by $82 \%$ of DE intakes as reported by NRC, (1996); Regadas Filho et al. (2011). The metabolizability (qm) was calculated as ME/GE for each experimental diet (AFRC, 1993; Regadas Filho et al., 2011).

\section{Chemical and statistical analyses}

Samples of the experimental feeds were analysed for proximate composition using the procedure of AOAC (2002) and data obtained from body weight gain and energy utilization were subjected to analysis of variance (ANOVA) using SAS (2001) at $\mathrm{P}<$ 0.05 level of significant. Means with significant differences were separated using the Duncan's multiple range test.

Table 1: Proximate composition of the experimental feeds

\begin{tabular}{lllllll}
\hline Component & URBM & PRBM & USBM & UBBM & FF & Concentrate \\
\hline Dry matter & 86.02 & 86.00 & 85.98 & 85.99 & 72.78 & 89.06 \\
Crude protein (\%DM) & 4.60 & 4.87 & 4.85 & 4.53 & 16.88 & 20.01 \\
Crude fibre (\%DM) & 5.01 & 5.33 & 5.29 & 5.20 & 25.74 & 13.00 \\
Ash (\%DM) & 3.82 & 3.95 & 2.72 & 3.09 & 11.31 & 7.98 \\
Ether extract (\%DM) & 2.41 & 2.91 & 2.11 & 2.56 & 3.30 & 1.09 \\
NFE (\%DM) & 84.16 & 82.94 & 85.03 & 83.92 & 36.77 & 57.92 \\
\hline
\end{tabular}

$\mathrm{URBM}=$ Unpeeled raw breadfruit meal, PRBM $=$ Peeled raw breadfruit meal, USBM = Unpeeled soaked breadfruit meal, $\mathrm{UBBM}=$ Unpeeled boiled breadfruit meal, $\mathrm{FF}=\quad$ Ficus foliage, NFE $=$ Nitrogen free extract

\section{Results and Discussion}

The proximate composition of the experiment feeds is shown in Table 1. The dry matter content ranged from $72.78 \%$ in Ficus foliage to $89.06 \%$ in concentrate diet. The crude protein and fibre values of breadfruit that ranged from $4.53 \%$ to $4.87 \%$ and $5.01 \%$ to $5.33 \%$ respectively were generally low. Hence, the need to add the Ficus foliage and concentrate diet that had $16.88 \%$ and $20.01 \%$ crude protein and $25.74 \%$ and $13.00 \%$ in crude fibre was necessary to augment the fibre content of the breadfruit meals and supply fermentable protein to balance the supplied nutrients from the breadfruit meals, which encourage rumen degradation as well as promote production. Ash content which ranged between $2.72 \%$ and $11.31 \%$ was lowest in USBM and highest in Ficus foliage. The lowest ash content of USBM could be due to leaching in water during soaking of the breadfruit (Amusa et al., 2002). Ether extract values $(1.09 \%$ to $3.30 \%)$ were lowest in concentration diet compared to differently processed breadfruit meal and Ficus foliage. Nitrogen free extract values of processed breadfruit meal $(82.94 \%$ and $85.03 \%$ ) were considerably high, indicating high energy content. The proximate composition of processed breadfruit meal in this study is similar to previous reports by Oladunjoye et al., (2010), while that of Ficus foliage is slightly different from earlier reports by Ajayi et al. (2005). The stage of maturity before harvesting and the specie could have 


\section{Okoruwa}

been responsible for the difference observed.

Presented in Table 2 is the result of energy utilization of ram-lambs fed differently processed breadfruit meal based diets. Significant difference $(\mathrm{P}<0.05)$ was observed in GE intake, with ram-lambs on $\operatorname{diet} \mathrm{D}(4503.00 \mathrm{MJ} / \mathrm{g} /$ day $\mathrm{DM})$ having a higher intake, followed by diets B (4316.13 MJ/g/day DM) and C $(4281.29 \mathrm{MJ} / \mathrm{g} /$ day DM) before those on diet $\mathrm{A}(3523.36 \mathrm{MJ} / \mathrm{g} /$ day DM). Boiling has been reported to reduce the nutritional value with losses and changes in major nutrients including protein, carbohydrates, minerals and vitamins (FAO, 1990) which possibly explained the increase that was observed in the GE intake by the ram-lambs on diet D for them to meet up their nutrient and energy requirements. Faecal energy output which ranged between $793.25 \mathrm{MJ} / \mathrm{g} /$ day $\mathrm{DM}$ and 999.41MJ/g/day DM was significantly $(\mathrm{P}<$
0.05 ) highest in diets A and D compared with diets $\mathrm{B}$ and $\mathrm{C}$. This result can probably be explained by imbalance levels of nutrient and energy utilization caused by inhibitory effects of residual toxic substances of unpeeled raw breadfruit meal in the $\operatorname{diet} \mathrm{A}$ and the losses of nutrient as a result of boiling effect of breadfruit meal in diet D. This is in conformity with the earlier reports of Emiola et al. (2007) who stated that though unpeeled raw breadfruit meal has a moderate level of anti-nutritional factors, their presence could influence higher faecal energy output in livestock. Urinary energy (UE) loss ranged from 0.50 to 0.72 $\mathrm{MJ} / \mathrm{g} /$ day and was not significantly $(\mathrm{P}$ $>0.05$ ) influenced by diets, though the nonsignificant higher numerical value of urinary energy of diet A also buttress the effect of poor nutrient and energy utilization in the diet.

Table 2: Energy utilization (MJ/g/day DM) of ram -lambs fed differently processed breadfruit meal based diets.

\begin{tabular}{lccccc}
\hline & \multicolumn{3}{c}{ Diets } & SEM \\
\cline { 2 - 5 } Parameters & $\mathbf{A}$ & $\mathbf{B}$ & $\mathbf{C}$ & $\mathbf{D}$ & SEM \\
\hline Gross energy intake & $3523.36^{\mathrm{c}}$ & $4316.13^{\mathrm{b}}$ & $4281.29^{\mathrm{b}}$ & $4503.00^{\mathrm{a}}$ & 1.02 \\
Faecal energy output & $999.41^{\mathrm{a}}$ & $793.25^{\mathrm{b}}$ & $820.94^{\mathrm{b}}$ & $942.66^{\mathrm{a}}$ & 0.42 \\
Urinary energy loss & $0.72^{\mathrm{a}}$ & 0.55 & 0.50 & 0.60 & 0.01 \\
Digestible energy intake & $1146.16^{\mathrm{c}}$ & $1310.84^{\mathrm{a}}$ & $1295.62^{\mathrm{a}}$ & $1249.24^{\mathrm{b}}$ & 0.75 \\
Metabolizable energy intake & $939.85^{\mathrm{c}}$ & $1074.89^{\mathrm{a}}$ & $1062.41^{\mathrm{a}}$ & $1024.38^{\mathrm{b}}$ & 0.93 \\
Metabolizable energy $\left(\mathrm{W}^{0.75}\right)$ & $169.74^{\mathrm{c}}$ & $187.73^{\mathrm{a}}$ & $186.09^{\mathrm{a}}$ & $181.07^{\mathrm{b}}$ & 0.68 \\
Metabolizability $(\mathrm{qm})$ & 0.82 & 0.82 & 0.82 & 0.82 & 0.03 \\
\hline
\end{tabular}

$\mathrm{a}, \mathrm{b}$ Means on the same row with different super scripts are significantly different $(\mathrm{P}<0.05)$. SEM $=$ standard error of means.

Digestible energy (DE) intake values of $1146.16,1310.84,1295.62$, and 1249.24 $\mathrm{MJ} / \mathrm{g} /$ day DM were obtained for ram-lambs on treatment diets $\mathrm{A}, \mathrm{B}, \mathrm{C}$ and $\mathrm{D}$ respectively. The significant $(\mathrm{P}<0.05)$ improvement DE observed in ram-lambs on dietary treatments $\mathrm{B}$ and $\mathrm{C}$ can be attributed to the processing effects on the breadfruit which reduced the level of antinutritional factors and increased the levels of energy availability compared to diets A and D. This is in line with the reports of Oladunjoye et al. (2010) who observed increase in DE when differently processed breadfruit meals were used in livestock feeds. Metabolizable energy intake values are often used as sensitive yardsticks for the determination of overall energy intake of a diet. It measures the metabolic sum of the process of digestion, absorption and utilization of a diet in energy unit (Adeyemi et al., 2006). Thus, the efficiency with 


\section{Weight gain of ram-lambs fed differently processed breadfruit meal}

which ME intake is retained depends on interaction of two principle factors: the nature of the chemical compounds in which the $\mathrm{ME}$ is contained and the purpose for which these compounds are used by the animals. The estimated ME observed, in this study, was significantly $(\mathrm{P}<0.05)$ higher in diets $\mathrm{B}(1074.89 \mathrm{MJ} / \mathrm{g} /$ day $\mathrm{DM})$ and $\mathrm{C}$ $(1062.41 \mathrm{MJ} / \mathrm{g} /$ day $\mathrm{DM})$ compared with diets A (939.85 $\mathrm{MJ} / \mathrm{g} /$ day $\mathrm{DM})$ and $\mathrm{D}$ (1024.38 MJ/day DM). The lower ME observed in diets A and D could probably be explained by the higher energy loss through faecal energy output that attributed to improper energy content from antinutritional factors and boiling effects of breadfruit meal. Metabolizable energy in $\mathrm{W}^{0.75}$ that ranged between 169.74 and 187.73 $\mathrm{MJ} / \mathrm{g} /$ day DM was significant $(\mathrm{P}<0.05)$, and followed the same trend as observed in ME. The ME in $\mathrm{W}^{0.75}$ values in this study were lower than the mean value of $380.00 \mathrm{MJ} / \mathrm{g} /$ day as earlier reported by Johnson et al. (2003). The metabolizability (qm) was insignificant $(\mathrm{P}>0.05)$ and generally low. The average metabolizability of $0.82 \mathrm{MJ} / \mathrm{g} /$ day $\mathrm{DM}$ in this study, was almost in line with the report of Amaefule and Udo (2009) who reported that metabolizability of complete feeds is relatively constant and equivalent to about $0.96 \mathrm{MJ} / \mathrm{g} /$ day DM.

Table 3: Growth response of ram-lambs fed experimental diets

\begin{tabular}{lccccc}
\hline & \multicolumn{3}{c}{ Diets } & \\
\cline { 2 - 5 } Parameters & A & B & C & D & SEM \pm \\
\hline Initial body weight $(\mathrm{kg})$ & 6.70 & 6.25 & 6.56 & 6.68 & 0.21 \\
Final body weight $(\mathrm{kg})$ & $8.07^{\mathrm{b}}$ & $10.43^{\mathrm{a}}$ & $10.69^{\mathrm{a}}$ & $8.95^{\mathrm{b}}$ & 0.16 \\
Average total weight gain $(\mathrm{kg})$ & $2.86^{\mathrm{b}}$ & $4.18^{\mathrm{a}}$ & $4.13^{\mathrm{a}}$ & $3.08^{\mathrm{b}}$ & 0.08 \\
Average daily weight gain $(\mathrm{g})$ & $59.58^{\mathrm{b}}$ & $87.08^{\mathrm{a}}$ & $86.04^{\mathrm{a}}$ & $64.17^{\mathrm{b}}$ & 0.04 \\
Average daily weight gain $\left(\mathrm{g} / \mathrm{W}^{0.75}\right)$ & $21.45^{\mathrm{b}}$ & $28.51^{\mathrm{a}}$ & $28.25^{\mathrm{a}}$ & $21.87^{\mathrm{b}}$ & 0.21 \\
Average total feed intake $(\mathrm{kg})$ & $10.57^{\mathrm{b}}$ & $12.90^{\mathrm{a}}$ & $12.82^{\mathrm{a}}$ & $13.68^{\mathrm{a}}$ & 0.39 \\
Average daily feed intake $(\mathrm{g})$ & $220.21^{\mathrm{c}}$ & $268.75^{\mathrm{b}}$ & $267.08^{\mathrm{b}}$ & $285.00^{\mathrm{a}}$ & 0.13 \\
Feed conversion ratio & $3.70^{\mathrm{a}}$ & $3.09^{\mathrm{b}}$ & $3.10^{\mathrm{b}}$ & $4.44^{\mathrm{a}}$ & 0.07 \\
\hline
\end{tabular}

$\mathrm{a}, \mathrm{b}$ Means on the same row with different superscript are significantly different $(\mathrm{P}<0.05)$. SEM $=$ standard error of means.

Table 3 presents growth response of ramlambs fed experimental diets. All growth parameters, in this study were significantly $(\mathrm{P}<0.05)$ affected by treatment diets. Final body weight was significantly $(\mathrm{P}<0.05)$ higher in diets $\mathrm{B}(10.43 \mathrm{~kg})$ and $\mathrm{C}(10.69 \mathrm{~kg})$ compared with diets A $(8.07 \mathrm{~kg})$ and D $(8.95 \mathrm{~kg})$. Average total and daily weight gains followed the same pattern as final body weight. Ram-lambs on diets $\mathrm{B}$ and $\mathrm{C}$ were significantly $(\mathrm{P}<0.05)$ heavier than those on $\operatorname{diet} \mathrm{A}$. The significantly $(\mathrm{P}<0.05)$ higher final body weight, and average total and daily body weight gain of ram-lambs on diets $\mathrm{B}$ and $\mathrm{C}$ could be as a result of the processing effect on the breadfruit meal which possibly reduced the level of anti- nutritional factors and increased the ability of the animal to properly utilize the feeds that must have supplied more energy and nutrients to the ram-lambs compared with those fed diets A and D. These results appear reasonable considering the higher digestible and metabolizable energy intakes of diets B and C (Table 3). Regadas Filho et al. (2011) reported that efficient utilization of feeds that supply adequate energy and protein with other nutrients is required for optimum BW gain in sheep. Feed intake is an important factor in the utilization of feed by livestock and is also a critical determinant of energy and protein availability for body weight gain in sheep (Ososanya, 2010). This opinion with the 
degree of acceptability inherent in the diets and physical nature of diets preparation might be responsible for the significant difference $(\mathrm{P}<0.05)$ obtained in the feed intake. Average total feed intakes of animals fed diets B $(12.90 \mathrm{~kg}), \mathrm{C}(12.82 \mathrm{~kg})$ and $\mathrm{D}(13.68 \mathrm{~kg})$ were higher than those fed $\operatorname{diet} \mathrm{A}(10.57 \mathrm{~kg})$. Average daily feed intake was highest and lowest $(\mathrm{P}<0.05)$ for ramlambs fed diets D (285.00g) and A $(220.12 \mathrm{~g})$ respectively. This depressed average daily feed intake of ram-lambs fed diet A could probably be attributed to adverse performance in terms of weight gain and energy utilization of the animals. In addition, the residual anti-nutritional factors and low acceptability of the feed could be other contributing factors that could have been responsible for the low feed intake observed. Feed conversion ratio (FCR), measured as feed intake per unit weight gain, was significantly $(\mathrm{P}<0.05)$ different among diets. The efficiency with which ram-lambs converted feeds for body weight gain was lower $(\mathrm{P}<0.05)$ in diets $\mathrm{B}$ (3.09) and $C$ (3.10) indicating better feed conversion ratio of the diets compared with diets A (3.70) and D (4.44). The higher average daily weight gain and better FCR in diets $\mathrm{B}$ and $\mathrm{C}$ attest to the superiority of these diets.

\section{Conclusion}

Base on the results obtained in this work, it is concluded that feeding of differently processed breadfruit meals with Ficus foliage and concentrate in a complete diet can be used in small ruminant nutrition to promote body weight gain, most especially during the dry season. However, the efficacy of peeling raw breadfruit and soaking of unpeeled raw breadfruit meals in improving the nutritive value of breadfruit meal is demonstrated by the superior feed intake, weight gain and feed utilization efficiency of the ram-lambs on these diets.

\section{References}

Adeyemi, O. A., Eruvbetine, D., Oguntona, T., Dipeolu, M. and Agunbiade, J. A. 2006 . Determination of the metabolizable energy value of whole cassava root meal fermented with rumen filtrate. Nigeria Poultry Science Journal 4: 26-33

AFRC 1993. Agricultural and Food Research Council. Energy and protein requirements of ruminants. Wallingford Commonwealth A gricultural Bureaux International. Pp 159.

Ahamefule, F. O. and Udo, M. D. 2010. Performance of West African Dwarf goats fed raw or processed pigeon pea (Cajanus cajan) seed meal based diets. Nigerian Journal of Animal Production 37(2): 227 236.

Ajayi, D. A., Adeneye, J. A. and Ajayi, F. T. 2005. Intake and nutrient utilization of West African Dwarf goats fed mango (Mangifera indica), ficus (Ficus thionningii), gliricidia (Gliciridia sepium) foliages and concentrates as supplements to based diet of guinea grass (Panicum maximum). World Journal of Agricultural Science 1(2): 184-189.

Amusa, N. A., Kehinde, L. A. and Ashaye, A. O. 2002. Biodeterioration of breadfruit in storage and its effect on nutrient composition. African Journal of Biotechnology 9(27): 4259-4263.

AOAC 2002. Official methods of analysis. (Association of Official Analytical Chemists) $14^{\text {th }}$ edition, Washington DC. Pp 141. 
Emiola, I. A., Ologhobo, A. D and Gous, R. M. 2007. Performance and histological responses of internal organs of broiler chicken fed raw dehulled and aqueous and dry heated kidney bean meals. Poultry Science 86: $1234-1240$

Fanimo, A. O., Sogunle, O. M., Husanmi, O. O. and Okorie, A. C. 2006. Evaluation of metabolizable energy values of some feeding stuffs for poultry. Nigerian Poultry Science Journal 4: 21-25.

FAO 1990. Food and Agriculture Organisation. Root tubers plantain and bananas: In human nutrition, FAO. Rome, Italy.

Johnson, D. E., Ferrel, C. L. and Jenkins T. G. (2003). The history of energy research: where have we been and where are we going. Journal of Animal Science 55: 1190-1199.

Kamalzadeh, A. and Shabani, A. 2007. Maintenace and growth requirements for energy and nitrogen of Baluchi sheep. International Journal of Agriculture and Biology 9(4): 535 539.

NRC 1996. National Research Council. Nutrient requirements of beef cattle. $7^{\text {th }}$ edition, Washington, D. C. $P p 242$

NRC 2007. National research Council. Nutrient requirements of small ruminant. Washington, D. C. National Academy Press. Pp 362

Okoruwa M. I. and Bamigboye, F. O. 2015. Performance characteristics of West African Dwarf goats fed sweet potato peels and cashew nut shell supplemented with Ocimum gratissium leaves. Advances in Life Science and Technology 35: 84-89
Oladunjoye, I. O., Ologhobo, A. D. and Olaniyi C. O. 2010. Nutrient composition, energy value and residual anti-nutritional factors in differently processed breadfruit (Artocarpus atlitis) meal. African Journal of Biotechnology 9(27): $4259-4263$

Ososanya, T. O. 2010. Effect of vary levels of broiler litter on growth performance and nutrient digestibility of West African Dwarf lambs. Nigerian Journal of Animal Science 12: 123-128.

Regadas Filho, J. G. L., Pereira, E.S.P., Villarroel, A. B. S., Pimentel, P. G., Fontenele, R. M., Ferreira Costa, M. R. G., Gomes Maia, L. S., Sombra. W. A. 2011. Efficiency of metabolizable energy utilization for maintenance and gain and evaluation of small ruminant nutrition system model in Santa Ines sheep. Revista Brasileira de Zootecnia 40(11): $2558-2564$

SAS 2001. Statistical Analysis System.SAS/STAT user's guide version 8 . SAS Insititue inc. Cary NC.

Zhou, Y., Taylor, M. B. and Underhill, S. J. R. 2014. Dwarfing of breadfruit (Artocarpus atlitis) trees: Opportunities and challenges. American Journal of Experimental Agriculture, 4(12): 1743 - 1763.

Received: $27^{\text {th }}$ August, 2016 Accepted: $23^{\text {rd }}$ February, 2017 